\title{
Penerapan Teknik Mozaik untuk Meningkatkan Motorik Halus Anak Kelompok A di TK Permata Bunda Kota Malang
}

\author{
Zahrok Noviana Wahyuningtyas*, Usep Kustiawan, Rosyidamayani Twinsari Maningtyas \\ Universitas Negeri Malang, Jl. Semarang No. 5 Malang, Jawa Timur, Indonesia \\ *Penulis korespondensi, Surel: zahroknoviana@gmail.com
}

Paper received: 2-1-2021; revised: 23-1-2021; accepted: 30-1-2021

\begin{abstract}
This research aims to improve the fine motoric of group A children in Permata Bunda kindergarten at Malang City through the mosaic technique. The research used Kemis and Mc Taggart's action research model. The results showed that the application of the mosaic technique can improve children's fine motor skills as evidenced by an increase from cycle 1 as big as 44,23 percent to be 85,58 percent in cycle 2 .
\end{abstract}

Keywords: mosaic technique; fine motor; group A children

\begin{abstract}
Abstrak
Penelitian ini bertujuan untuk meningkatkan motorik halus anak kelompok A di TK Permata Bunda Kota Malang melalui teknik mozaik. Penelitian menggunakan penelitian tindakan kelas model Kemis dan Mc Taggart. Hasil penelitian menunjukkan bahwa penerapan teknik mozaik dapat meningkatkan motorik halus anak terbukti dengan adanya peningkatan dari siklus 1 sebesar 44,23 persen menjadi 85,58 persen pada siklus 2 .
\end{abstract}

Kata kunci: teknik mozaik; motorik halus; anak kelompok A

\section{Pendahuluan}

Usia dini merupakan usia emas yang mana pada usia ini merupakan masa terjadinya kematangan fungsi-fungsi baik dari segi fisik maupun psikis yang siap merespon dan menerima rangsangan yang diberikan oleh lingkungan. Salah satu aspek perkembangan anak usia dini yang perlu diperhatikan perkembangannya serta diberikan stimulus atau rangsangan yang tepat adalah perkembangan motorik halus. Motorik halus menurut pendapat Mursid (2015) adalah suatu gerakan yang merupakan hasil koordinasi antar otot-otot kecil yang menuntut adanya kemampuan dalam mengontrol gerakan secara sederhana. Sejalan dengan Departemen Pendidikan Nasional (2008) yang mengemukakan bahwa motorik halus adalah gerakan yang melibatkan bagian-bagian tubuh tertentu dalam melakukan suatu aktivitas yang diperankan oleh otot-otot kecil serta memerlukan koordinasi yang cermat, seperti menggunting, mengikuti garis, menulis, meremas, menggambar, menyusun balok, menyusun manik-manik, menggunakan kuas, serta melipat. Sumantri (2005) mengemukakan bahwa motorik halus adalah pengorganisasian sekelompok otot-otot kecil seperti jari-jemari dan tangan yang sering membutuhkan kecermatan dan koordinasi mata dengan tangan dalam penerapannya.

Pentingnya atau urgensi perkembangan motorik halus pada anak usia dini adalah untuk meningkatkan kemampuan mengelola, mengolah, mengontrol, mengkoordinasi, serta meningkatkan keterampilan tubuh sehingga dapat menunjang pertumbuhan motorik yang terampil. Berdasarkan hasil pengamatan di TK Permata Bunda Kota Malang pada akhir bulan Januari 2019 sampai bulan Februari 2019, dalam proses pembelajaran terutama dalam 
kegiatan menjumput, menempel, dan menyusun potongan kertas menunjukkan bahwa sebagian besar keterampilan motorik halus anak masuk dalam kategori belum berkembang. Data yang diperoleh menunjukkan bahwa hanya 5 anak dari 17 anak atau sebesar 29,41\% anak usia 4-5 tahun telah dapat menunjukkan keterampilan motorik halusnya. Mereka telah mampu menggerakkan jari jemari tangan serta koordinasi tangan dengan mata. Sedangkan, sisanya yakni 12 anak atau sebesar 70,59\% anak usia 4-5 tahun belum mampu menunjukkan kemampuan motorik halusnya. Perkembangan motorik yang lebih menonjol pada anak tersebut adalah motorik kasarnya.

Untuk mengatasi permasalahan tersebut, peneliti membuat kegiatan pembelajaran yang dapat meningkatkan aspek perkembangan anak usia dini khususnya dalam aspek perkembangan motorik halus yaitu teknik mozaik. Teknik mozaik menurut Kustiawan (2016) adalah sebuah teknik dalam menggambar yang dibuat dengan cara mengisi bahan pada bidang-bidang sebuah gambar. Setiap bidang pada gambar diisi dengan satu jenis bahan. Bahan yang digunakan berupa bahan utuh atau bahan yang telah menjadi potongan dan disusun secara berdampingan dengan jarak pemisah yang teratur sehingga hasilnya rapi. Mozaik menurut Pamadhi \& Sukardi (2008) adalah pembuatan karya seni dua dimensi atau tiga dimensi yang menggunakan bahan dari kepingan-kepingan yang sengaja dibuat dengan cara dipotong sama besar kemudian disusun dengan cara ditempelkan menggunakan lem. Sejalan dengan Sumanto (2005) yang menyatakan bahwa teknik mozaik adalah suatu cara membuat kreasi gambar, lukisan, dan hiasan yang dilakukan dengan cara menempelkan atau merekatkan potongan bahan tertentu pada satu pola gambar yang memiliki makna tertentu. Berdasarkan uraian di atas, maka akan dilakukan penelitian dengan judul "Penggunaan Teknik Mozaik untuk Meningkatkan Motorik Halus Anak Kelompok A di TK Permata Bunda Kota Malang”.

\section{Metode}

Pendekatan yang digunakan oleh peneliti dalam penelitian ini adalah pendekatan deskriptif kualitatif dan deskriptif kuantitatif dengan rancangan Penelitian Tindakan Kelas (PTK). Menurut Arikunto, dkk (2014) PTK adalah suatu kegiatan penelitian yang dilakukan dengan mencermati proses belajar mengajar dalam sebuah kelas yang dilakukan secara sengaja dengan tujuan tertentu. Tujuan PTK adalah untuk mengatasi permasalahan yang ada di kelas dan untuk meningkatkan kualitas suatu pembelajaran di kelas. Penelitian ini menggunakan model yang dikemukakan oleh Kemis \& Mc Taggart. Model tersebut merupakan model penelitian bersiklus yang setiap siklus terdiri dari planning, acting \& observing, reflecting, dan revice plan.

Subjek penelitian adalah anak kelompok A TK Permata Bunda Kota Malang pada tahun ajaran 2018/2019. Anak kelompok A TK PKK Permata Bunda Kota Malang berjumlah 17 anak yang terdiri dari 8 anak perempuan dan 9 anak laki-laki. Data yang digunakan dalam penelitian ini berupa data aktivitas guru, data ketercapaian perkembangan motorik halus anak, data wawancara, data dokumentasi dan data catatan lapangan. Sumber data dalam penelitian ini adalah anak dan guru kelompok A TK Permata Bunda Kota Malang. Anak kelompok A sebagai subjek yang diamati oleh peneliti, sedangkan guru kelas kelompok A sebagai pelaksana kegiatan mengajar dan sebagai narasumber informasi yang dibutuhkan. Analisis data yang digunakan dalam penelitian ini adalah deskriptif kualitatif dan deskriptif kuantitatif. Data yang termasuk dalam sumber kualitatif adalah hasil observasi aktivitas guru, hasil wawancara, hasil dokumentasi dan catatan lapangan. Data yang termasuk dalam sumber kuantitatif adalah hasil instrumen penilaian capaian perkembangan motorik halus anak dalam teknik mozaik. 
Data kualitatif dianalisis menggunakan tahapan pengumpulan data, penyederhanaan data, penyajian data dan refleksi. Pada tahap awal analasisis data kualitatif, semua data dari aktivitas guru, hasil wawancara, hasil dokumentasi dan hasil catatan lapangan dikumpulkan setelah itu data yang diperoleh disederhanakan untuk disajikan guna pengambilan tindakan pada tahap refleksi. Data kuantitatif dianalisis menggunakan rumusan persentase dan diwujudkan dalam bentuk persentase. Rumusan untuk persentase ketercapaian klasikal menurut Trianto (2010:241) sebagai berikut.

Tabel 1. Kriteria ketercapaian kelas

\begin{tabular}{ccc}
\hline Kriteria & Persentase Ketercapaian Kelas & Tingkat Ketercapaian \\
\hline BSB & $85 \%-100 \%$ & Sangat Baik \\
BSH & $75 \%-84 \%$ & Baik \\
MB & $38 \%-74 \%$ & Cukup \\
BB & $0 \%-37 \%$ & Kurang \\
\hline
\end{tabular}

Berdasarkan kriteria ketercapaian penilaian yang telah ditentukan maka dapat disimpulkan bahwa batas minimal nilai keberhasilan dalam penelitian ini adalah sebesar $75 \%$. Persentase kemampuan motorik halus dikatakan meningkat apabila kriteria ketercapaian kelas telah memenuhi persentase sebesar 75\%-100\%.

\section{Hasil dan Pembahasan}

Pada tahap pra tindakan peneliti mengamati permasalahan yang terjadi selama proses pembelajaran berlangsung. Peneliti mengkhususkan aspek yang diamati berkaitan dengan motorik halus anak yang meliputi kegiatan menjumput, menyusun, dan menempel. Hasil analisis dari pra tindakan menunjukkan bahwa sebagian besar anak belum mampu menjumput potongan kertas menggunakan dua ujung jari, belum mampu menempel kertas menggunakan perekat, dan belum mampu menyusun potongan kertas pada pola gambar hingga selesai. Data yang diperoleh menunjukkan bahwa dari jumlah keseluruhan anak kelompok A, terdapat 12 anak yang tergolong belum mampu dalam kemampuan motorik halusnya.

Pada siklus 1 proses pembelajaran dilaksanakan selama dua kali pertemuan. Hasil penilaian capaian perkembangan motorik halus anak selama melakukan kegiatan mozaik pada siklus 1 pertemuan pertama menunjukkan bahwa anak rata-rata belum mampu menjumput potongan kertas dengan konsisten sehingga kehabisan waktu dalam memberi lem pada potongan kertas dan mengakibatkan keterlambatan dalam menyusun potongan kertas ke pola gambar. Pada pertemuan pertama persentase ketercapaian kelas yang didapat telah mengalami peningkatan dari persentase pra tindakan, meskipun peningkatan yang didapatkan belum memenuhi ketercapaian. Persentase yang didapat sebesar 38,46\% dengan kategori mulai berkembang. Pada siklus 1 pertemuan kedua persentase ketercapaian kelas mulai meningkat menjadi 50\%. Namun, kategori ketercapaian kelas masih termasuk dalam kategori mulai berkembang. Berdasarkan hasil persentase di atas, rata-rata persentase ketercapaian kelas pada siklus 1 adalah sebesar 44,23\%. Persentase tersebut telah mengalami peningkatan sebesar $14,82 \%$ dari persentase pada tahap pra tindakan. Meskipun terdapat peningkatan dari tahap pra tindakan ke tahap siklus 1 akan tetapi persentase tersebut masih masuk ke dalam kriteria mulai berkembang dan belum memenuhi tingkat ketercapaian yang diharapkan.

Berdasarkan hasil refleksi pada siklus 1 maka peneliti bersama guru kelas melakukan rencana perbaikan yang akan dijalankan pada siklus 2. Perbaikan yang dilakukan yaitu 
menjelaskan langkah-langkah dengan lebih berhati-hati agar tidak ada langkah yang terlewati serta lebih mendetail agar anak benar-benar paham, melakukan pendampingan pada anak yang membutuhkan pendampingan dan selalu memberikan motivasi pada anak untuk melakukan mozaik dengan baik, mengganti potongan kertas dari bentuk persegi panjang ke bentuk segitiga serta mengganti kertas karton dengan media tiga dimensi berupa mangkuk plastik.

Pelaksanaan teknik mozaik pada siklus 2 terdiri dari dua kali pertemuan. Pada siklus 2 pertemuan pertama persentase kelas yang dicapai sebesar $81,8 \%$ dengan kategori berkembang sesuai harapan. Sedangkan, persentase ketercapaian kelas yang terdapat pada siklus 2 pertemuan kedua sebesar 90,9\% dengan kategori berkembang sangat baik. Persentase rata-rata yang diperoleh pada siklus 2 adalah sebesar 85,58\% dengan kategori berkembang sangat baik. Persentase pada siklus 2 telah mengalami peningkatan sebesar 41,35\% dari persentase pada siklus 1 . Kriteria tingkat ketercapaian kelas dalam siklus 2 termasuk dalam kategori berkembang sangat baik. Peningkatan yang terjadi pada siklus 2 telah menunjukkan hasil yang maksimal dan telah memenuhi tingkat ketercapaian yang telah ditargetkan. Hal yang sangat berpengaruh dalam meningkatkan kemampuan motorik halus anak adalah penerapan teknik mozaik yang menggunakan benda berbentuk tiga dimensi dan peran guru yang maksimal dalam pemberian stimulus yang baik. Dilihat dari adanya peningkatan dari siklus 1 ke siklus 2 secara signifikan maka dapat diambil kesimpulan bahwa teknik mozaik dapat meningkatkan kemampuan motorik halus anak khususnya pada anak kelompok A di TK Permata Bunda Kota Malang.

Penerapan teknik mozaik dalam penelitian ini mengacu pada langkah-langkah penerapan kegiatan mozaik yang diungkapkan oleh Sumanto (2005) yaitu: guru mempersiapkan kertas gambar atau kertas karton sesuai dengan ukuran yang diinginkan, guru mempersiapkan potongan bahan yang akan ditempel, guru mempersiapkan lem dan alat yang lain, guru mendemonstrasikan langkah kerja membuat mozaik mulai dari membuat pola gambar dan menyiapkan potongan bahan yang akan ditempel, lalu memberi lem dan menempelkan potongan gambar pada pola gambar yang tersedia. Pada saat pelaksanaan kegiatan mozaik, guru melakukan modifikasi terhadap pelaksanaan penerapan teknik mozaik. Modifikasi dilakukan oleh guru untuk menyesuaikan permasalahan yang harus diatasi di TK Permata Bunda dan modifikikasi tersebut digunakan untuk penyesuaian karakteristik subjek penelitian yang ada di TK Permata Bunda. Langkah penerapan teknik mozaik yang telah dilakukan oleh guru dijabarkan sebagai berikut.

Langkah awal yang dilakukan oleh guru adalah mempersiapkan alat dan bahan yang akan digunakan dalam teknik mozaik. Alat dan bahan yang digunakan pada siklus 1 meliputi kertas karton, kertas HVS yang telah diberi pola gambar, potongan kertas berbentuk persegi panjang dan lem. Sedangkan alat dan bahan yang digunakan dalam siklus 2 meliputi mangkuk plastik, kertas HVS, potongan kertas berbentuk segitiga dan lem. Langkah kedua, menunjukkan pola gambar yang telah dibuat sebelumnya oleh guru. Pola gambar terlebih dahulu ditunjukkan ke anak sebab karakteristik belajar anak adalah melalui pembelajaran yang nyata atau konkret. Maka dari itu, pola gambar perlu ditunjukkan terlebih dahulu ke anak agar anak lebih paham dan mengerti tentang kegiatan mozaik yang dilakukannya. Pola gambar yang ada pada siklus 1 meliputi gambar gedung sekolah dan gedung rumah sakit yang ditempelkan di atas kertas karton, sedangkan pola gambar pada siklus 2 meliputi gambar segitiga yang ditempelkan pada mangkuk plastik. 
Langkah ketiga, guru memberi contoh serta menjelaskan langkah-langkah cara pembuatan teknik mozaik. Guru memberi contoh cara menjumput potongan kertas yang benar menggunakan kedua ujung jari setelah itu potongan kertas yang telah diambil diberi lem secukupnya agar potongan kertas yang diambil tidak basah karena terlalu banyak diberi lem. Respons anak saat guru mendemonstrasikan langkah menjumput dan menempel adalah anak memperhatikan dengan seksama meskipun terdapat beberapa anak yang kurang dapat memperhatikan dengan baik. Anak yang kurang memperhatikan saat guru mendemonstrasikan langkah menjumput dan menempel belum dapat menjumput menggunakan kedua ujung jari dan terlalu banyak saat membubuhkan lem pada potongan kertas. Selanjutnya guru mencontohkan cara menyusun potongan kertas pada pola gambar yang telah tersedia. Langkah terakhir yang dilakukan oleh guru adalah merefleksi hasil karya mozaik yang telah dibuat oleh anak. Refleksi dilakukan pada setiap akhir pembelajaran untuk mengetahui hasil karya mozaik yang telah dibuat oleh anak dan refleksi tersebut dilakukan dengan melibatkan semua anak agar anak mengetahui hasil yang telah dibuat apakah sudah sesuai atau belum dengan langkah-langkah yang dicontohkan oleh guru.

Penggunaan teknik mozaik pada siklus 1 terlihat adanya kesulitan yang dialami oleh anak, kesulitan disebabkan oleh kurang mendetailnya penjelasan guru dan kurangnya pendampingan guru dalam pelaksanaan teknik mozaik serta potongan kertas yang digunakan terlalu kecil dan kertas karton yang digunakan kurang menarik bagi anak. Setelah mendapat hasil data siklus 1, peneliti melakukan perbaikan pada pembelajaran dalam siklus 2 . Pelaksanaan pembelajaran siklus 2 kurang lebih sama dengan siklus 1 namun dengan memperbaiki aktivitas yang dilakukan oleh guru serta memperbaiki potongan kertas dan bahan yang digunakan mozaik. Hasil yang diperoleh pada siklus 2 telah mengalami peningkatan dengan kriteria berkembang sangat baik. Berdasarkan paparan di atas, menunjukkan hasil bahwa melalui teknik mozaik dapat meningkatkan motorik halus anak usia dini. Hal tersebut sejalan dengan pendapat Sitepu \& Janita (2016) yang menyebutkan bahwa teknik mozaik bermanfaat untuk melatih motorik halus anak sebab dalam kegiatan mozaik anak menggunakan keterampilan jari jemarinya saat mengambil potongan benda dan melibatkan koordinasi antara mata dengan tangan.

\section{Simpulan}

Berdasarkan hasil penelitian tindakan kelas yang dilaksanakan dan pembahasan yang telah diuraikan di atas, dapat diambil kesimpulan bahwa: (1) penerapan kegiatan pembelajaran menggunakan teknik mozaik dapat meningkatkan kemampuan motorik halus anak kelompok A di TK Permata Bunda Kota Malang, dengan langkah-langkah pembelajaran sebagai berikut: (a) Guru menyiapkan alat dan bahan mozaik serta contoh hasil karya mozaik, (b) Guru memberi kesempatan pada anak untuk mengamati dan bertanya tentang contoh hasil karya mozaik, alat dan bahan yang disediakan, (c) Guru memberikan penjelasan terhadap alat dan bahan yang disediakan, (d) Guru memberikan penjelasan tentang teknik mozaik, (e) Guru mendemonstrasikan cara menjumput kertas, cara memberi lem pada potongan kertas dan cara menyusun potongan kertas, (f) Guru membimbing anak saat melakukan kegiatan mozaik, (g) Guru memberi motivasi pada anak saat kegiatan mozaik, (h) Guru melakukan refleksi terhadap hasil mozaik yang telah dibuat oleh anak; (2) Penerapan kegiatan menggambar teknik mozaik terbukti dapat meningkatkan tiga aspek kemampuan motorik halus anak yakni aspek menjumput, menempel dan menyusun. Hasil peningkatan persentase dari siklus 1 ke siklus 2 sebesar 41,35\%. Pada siklus 1 ketercapaian motorik halus anak sebesar $44,23 \%$ dan pada siklus 2 ketercapaian motorik halus anak mencapai 85,58\%. 
Berdasarkan pemaparan di atas dan hasil yang diperoleh pada penerapan teknik mozaik untuk meningkatkan kemampuan motorik halus anak, berikut merupakan saran-saran yang dapat dijadikan sebagai bahan pertimbangan bagi kemajuan di masa yang akan datang. Saran bagi guru diharapkan guru dapat menerapkan teknik mozaik secara berulang-ulang yang telah disesuaikan dengan tema pembelajaran untuk membantu stimulasi perkembangan motorik halus anak. Saran bagi peneliti lain adalah disarankan untuk mengkombinasikan teknik mozaik dengan media atau metode lain yang lebih inovatif agar dapat membantu stimulasi aspek perkembangan yang lainnya.

\section{Daftar Rujukan}

Arikunto, S. (2014). Penelitian Tindakan Kelas. Jakarta: Bumi Aksara.

Departemen Pendidikan Nasional. (2008). Pedoman Pembelajaran Bidang Pengembangan Fisik Motorik di Taman Kanak-kanak. Jakarta: Depdiknas.

Kustiawan, U. (2016). Pendidikan Menggambar. Universitas Negeri Malang.

Mursid. (2015). Belajar dan Pembelajaran PAUD. Bandung: PT. Remaja Rosdakarya.

Pamadhi, H \& Sukardi, E. (2008). Seni Keterampilan Anak. Jakarta: Universitas Terbuka.

Sitepu, J. M., \& Janita, S. R. (2017). Meningkatkan Kemampuan Motorik Halus Anak Melalui Teknik Mozaik Di Raudhatul Athfal Nurul Huda Kecamatan Sunggal Kabupaten Deli Serdang. Intiqad: Jurnal Agama dan Pendidikan Islam, 8(2), 73-83.

Sumanto. (2005). Pengembangan Kreativitas Seni Rupa Anak TK. Jakarta: Departemen Pendidikan Nasional Direktorat Jenderal Pendidikan Tinggi Direktorat Pembinaan Pendidikan Tenaga Kependidikan dan Ketenagaan Perguruan Tinggi.

Sumantri. (2005). Model Pengembangan Keterampilan Motorik Anak Usia Dini. Jakarta: Depdiknas.

Trianto. (2010). Mengembangkan Model Pembelajaran Tematik. Jakarta: PT Prestasi Pustaka. 